\title{
Pengembangan Bahan Ajar Berbasis Literasi Sains Materi Suhu dan Kalor
}

\author{
A. D. Paramita ${ }^{1}$,A. Rusilowati ${ }^{2}$, dan Sugianto $^{3}$ \\ Jurusan Fisika Fakultas Matematika dan Ilmu Pengetahuan Alam \\ Universitas Negeri Semarang \\ email: antaniadhana@yahoo.com ${ }^{1}$,rusilowati@yahoo.com ${ }^{2}$, sugianto_fis@yahoo.com ${ }^{3}$
}

\begin{abstract}
Abstrak
Tujuan penelitian ini adalah mengembangkan bahan ajar berbasis literasi sains materi suhu dan kalor.Jenis penelitian yang digunakan adalah penelitian dan pengembangan dengan subjek ujicoba siswa kelas X SMA 1 Bae Kudus tahun pelajaran 2015/2016. Pengambilan sampel dilakukan dengan teknik simple random sampling. Uji kelayakan dan keterbacaan menggunakan angket dan tes rumpang sedangkan uji keefektifan menggunakan PretestPosttest Control Group Design.Produk akhir penelitian ini berupa bahan ajar yang memiliki muatan literasi sains dengan perbadingan 2:1:1:1. Hasil analisis kelayakan dan keterbacaan menunjukkan bahwa bahan ajar memiliki kriteria sangat layak dan mudah dipahami dengan persentase keterbacaan $74,11 \%$.Uji gain menunjukkankemampuan literasi sains kelas eksperimen sebesar 0,63 sedangkan kelas kontrol 0,38. Hasil tersebut menunjukkanbahwa terdapat perbedaan peningkatan kemampuan literasi sains antara siswa yang menggunakan bahan ajar yang dikembangkan dengan bahan ajar yang digunakan di sekolah.
\end{abstract}

Kata Kunci:suhu dan kalor, bahan ajar, literasi sains

Kata kunci : suhu dan kalor, bahan ajar, sains literasi

\section{PENDAHULUAN}

Perkembangan ilmu pengetahuan dan teknologi yang terjadi selama dua dekade terakhir telah mengantarkan masyarakat memasuki era global.Setiap individu di era global dituntut mampu mengembangkan kemampuannya untuk bersaing di tingkat internasional. Salah satu cara pemerintah untuk memperoleh sumber daya manusia agar dapat bersaing di era global adalah dengan melakukan upaya peningkatan kualitas pendidikan (Rusilowati, 2013).

Programme for International Student Assessment (PISA) merupakan studi yang bertujuan untuk mengetahui hasil sistem pendidikan yang berkaitan dengan kemampuan literasi siswa usia 15 tahun. Studi PISA dilakukan di beberapa negara maju dan berkembang mulai tahun 2000 dengan interval tiga tahun sekali. Bidang kajian yang diteliti dan dinilai meliputi literasi membaca (reading literacy), literasi matematika (mathematical literacy), dan literasi sains (scientific literacy). Hasil studi PISA sejak tahun 2000 hingga tahun 2012 menunjukkan peringkat Indonesia terus menurun. Tahun 2012 literasi sains siswa Indonesia berada pada tingkat 64 dari 65 negara peserta dengan skor 382. Skor ini masih jauh di bawah skor rata-rata Internasional yang ditetapkan PISA yaitu 500 (PISA, 2012:5). Skor rata-rata Indonesia yang masih tergolong rendah ini mencerminkan bahwa siswa di Indonesia 
sebagian besar belum mampu menganalisis dan mengaplikasikan konsep untuk menyelesaikan suatu masalah. Para siswa sangat pandai menghafal, namun masih kurang terampil dalam menggunakan pengetahuan yang dimilikinya.

Rendahnya kemampuan literasi sains siswa di Indonesia juga dipengaruhi oleh pemilihan bahan ajar yang dipakai di sekolah. Bahan ajar memegang peranan penting dalam proses pembelajaran, yaitu sebagai media penyampaian informasi. Dengan demikian dibutuhkan bahan ajar yang baik agar tujuan pembelajaran dicapai secara maksimal. Bahan ajar yang baik adalah bahan ajar yang memuat komponen literasi sains secara seimbang. Wilkinson (1999) mengemukakan kategori literasi sains yang mendekati proporsi seimbang yaitu $42 \%$ untuk kategori pengetahuan sains, $19 \%$ penyelidikan hakikat sains, $19 \%$ kategori sains sebagai cara berpikir, dan 20\% interaksi sains, teknologi, dan masyarakat.

Maturradiyah, N \&A. Rusilowati (2015) melakukan pengujian terhadap tiga buku ajar fisika SMA kelas XI yang digunakan di kabupaten Pati. Hasil penelitian menunjukkan bahwa buku ajar fisika yang digunakan dalam proses pembelajaran umumnya menekankan pada aspek pengetahuan sains.Persentase komponen sains sebagai batang tubuh pengetahuan sebesar 70,94\%, sains sebagai cara untuk menyelidiki 7,08\%, sains sebagai cara berfikir sebesar 19,08\%, dan interaksi antara sains, teknologi dan masyarakat sebesar 2,90\%.

Selain studi pustaka, penulis juga melakukananalisis terhadap dua buku ajar fisika SMA kelas X. Hasil analisis menyatakan bahwa kedua buku tersebut paling banyak memuat kategori pengetahuan sains sebesar 54,44\% dan 29,18\% berisi kategori penyelidikan hakikat sains Kategori interaksi sains, teknologi, dan masyarakat memiliki persentase sebesar $12,14 \%$, dan kategori yang sedikit muncul adalah kategori cara berpikir dengan jumlah persentase sebesar $4,22 \%$.

Berdasarkan latar belakang tersebut, sebagian besar bahan ajar yang beredar dan digunakan di sekolah belum memuat komponen literasi sains secara seimbang. Dengan demikian, peneliti bermaksud mengembangkan bahan ajar yang memiliki komposisi literasi sains yang seimbang, mudah dipahami, layak dan efektif digunakan pada siswa SMA.

\section{METODE PENELITIAN}

Penelitian ini menggunakan metode penelitian dan pengembangan atau Research and Development (R\&D) yang menghasilkan produk akhir berupa bahan ajar berbasis literasi sains materi suhu dan kalor. Desain penelitian menurut Sugiyono (2011) dilakukan melalui 10 langkah seperti ditunjukkan pada Gambar 1. 


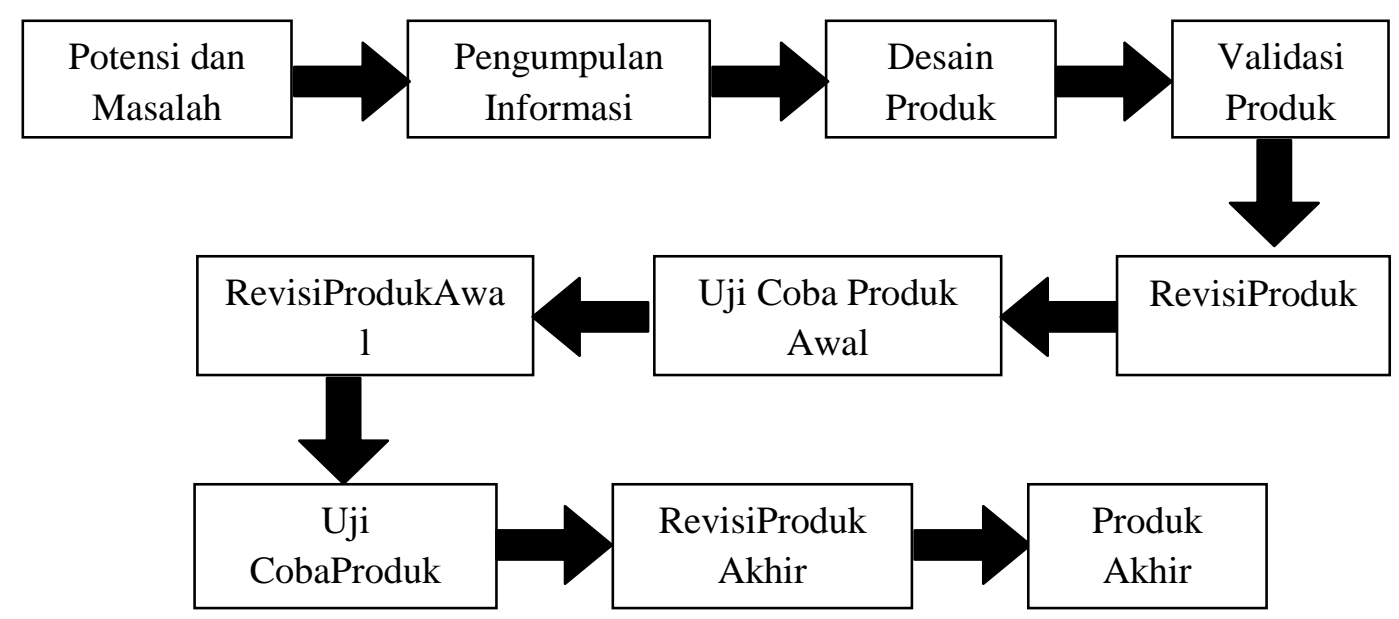

Gambar 1. Langkah-langkah Penelitian R \& D

Validasi produk dilakukan melalui dua tahap, yaitu validasi desain dan validasi produk. Validasi desain dilakukan oleh dosen pembimbing I dan dosen pembimbing II selaku pakar ahli. Validasi ini bersifat judgement experts. Selanjutnya validasi produk dilakukan oleh satu dosen Fisika dan dua guru Fisika SMA. Pengujian validitas produk menggunakanangket kelayakan bahan ajar untuk menilai kesesuaian isi materi, penyajian materi, bahasa, grafis dan muatan literasi sains.

Penelitian dilakukan di SMA Negeri 1 Bae Kudus. Langkah awal adalah melakukan uji kesamaan dua varians untuk mengetahui homogenitas populasi. Karena populasi bersifat homogen, maka sampel dipilih menggunakan teknik simple random sampling. Kelas X MIA 7 sebagai kelas kontrol dan kelas X MIA 4 sebagai kelas eksperimen.Ujicoba produk awal berupa uji keterbacaan menggunakan tes rumpang dengan 38 siswakelas X MIA 4 sebagai responden.Ujicoba produk akhir dilakukan dengan Pretest-Posttest Control Group Design.

Setelah memilih sampel penelitian, dilakukan pretest kepada 38 siswa kelas kontrol dan 38 siswa kelas eksperimen. Soal pretest terdiri dari 10 soal uraian.Hasilpretestini digunakan untuk mengetahui kemampuan awal siswa. Tahap selanjutnya kelas eksperimen melakukan pembelajaran menggunakan bahan ajar berbasis literasi sains dan kelas kontrol menggunakan bahan ajar yang digunakan di sekolah.

Peningkatan kemampuan literasi sains siswa diuji menggunakan uji gain berdasarkan nilai pretest dan posttest kelas kontrol dan kelas eksperimen. Hasil uji normalitasgain menunjukkan bahwa data tersebut terdistribusi normal sehingga analisis hipotesis menggunakan teknik statistik parametris. Pengujian hipotesis dilakukan dengan uji kesamaan dua rata-rata (uji t pihak kanan) untuk mengetahui perbedaan peningkatan kemampuan literasi sains siswa antara kelas eksperimen dan kelas kontrol. 


\section{HASIL DAN PEMBAHASAN}

Produk yang dihasilkan pada penelitian ini adalah bahan ajar berbasis literasi sains materi suhu dan kalor yang digunakan pada siswa kelas X Sekolah Menengah Atas. Data hasil penelitian meliputi karakteristik bahan ajar berbasis literasi sains, hasil uji kelayakan bahan ajar, hasil uji keterbacaan bahan ajar dan hasil analisis kemampuan literasi sains siswa.

Bahan ajar berbasis literasi sains yang dikembangkan mengambil materi suhu dan kalor, meliputi pokok bahasan suhu dan termometer, pemuaian, kalor dan perubahan wujud zat serta perpindahan kalor. Komposisi setiap aspek literasi sains dapat dilihat pada Tabel 1.

Tabel 1. Komposisi Aspek Literasi Sains dalam Bahan Ajar

\begin{tabular}{lccccc}
\hline \multirow{1}{*}{\begin{tabular}{c} 
Aspek Literasi \\
\multicolumn{1}{c}{ Sains }
\end{tabular}} & $\begin{array}{c}\text { Suhu dan } \\
\text { Termometer }\end{array}$ & Pemuaian & $\begin{array}{r}\text { Kalor dan } \\
\text { Perubahan } \\
\text { Wujud Zat }\end{array}$ & $\begin{array}{c}\text { Perpindahan } \\
\text { Kalor }\end{array}$ & $\begin{array}{c}\text { Rata- } \\
\text { rata }\end{array}$ \\
\cline { 2 - 5 } & & & $41,67 \%$ & $35,29 \%$ & $37,89 \%$ \\
$\begin{array}{l}\text { Sains sebagai batang } \\
\text { tubuh pengetahuan }\end{array}$ & $35,71 \%$ & $38,89 \%$ & & & \\
$\begin{array}{l}\text { Sains sebagai cara } \\
\text { menyelidiki }\end{array}$ & $21,43 \%$ & $22,22 \%$ & $25,00 \%$ & $11,76 \%$ & $20,10 \%$ \\
$\begin{array}{l}\text { Sains sebagai cara } \\
\text { berpikir }\end{array}$ & $28,57 \%$ & $22,22 \%$ & $16,67 \%$ & $23,53 \%$ & $22,75 \%$ \\
$\begin{array}{l}\text { Interaksi sains, } \\
\text { teknologi dan }\end{array}$ & $14,29 \%$ & $16,67 \%$ & $16,67 \%$ & $29,41 \%$ & $19,26 \%$ \\
masyarakat & & & & & \\
\hline
\end{tabular}

Pada pokok bahasan perpindahan kalor, aspek pertama yaitu sains sebagai batang tubuh pengetahuan tertuang dalam fitur Ayo Belajar. Fitur Ayo Belajar berisifakta dan konsep cara perpindahan kalor yang meliputi konduksi, konveksi dan radiasi.Aspek sains sebagai cara menyelidiki mengajak siswa untuk membuat kalkulasimisalnya menghitung laju radiasi matahari yang sampai di bumi. Aspek sains sebagai cara berpikir diwakilkan oleh fitur Ayo Berpikir. Fitur ini membahas prinsip kerja radiator mobil yang memanfaatkan proses konveksi paksa.

Aspek interaksi sains, teknologi dan masyarakat diwakilkan oleh fitur sains dalam kehidupan yang memaparkan teknologi bangunan hangat Finlandia. Pada wacana tersebut dijelaskan bagaimana penggunaan konsep perpindahan kalor (sains)dalam pembuatan rumah 
hangat (teknologi) yang dapat melindungi penghuninya pada cuaca sangat dingin (masyarakat) dengan menggunakan bahan kayu yang tidak mencemari lingkungan.Keterkaitan antarunsur sains, teknologi, masyarakat dan lingkungan tersebut memungkinkan siswa menggunakan sains dalam teknologi untuk memenuhi kebutuhannya tanpa merusak lingkungan (Rusilowati, A., Supriyadi \& A. Widiyatmoko, 2015).

Berdasarkan hasil analisis diperoleh perbandingan muatan literasi sains dalam bahan ajar yang dikembangkan meliputi sains sebagai batang tubuh pengetahuan, sains sebagai cara menyelidiki, sains sebagai cara berpikir dan interaksi antara sains, teknologi dan masyarakat adalah $37,89 \%: 20,10 \%: 22,75 \%: 19,26 \%$.

Wilkinson (1999) melakukan pemeriksaan terhadap isi beberapa buku teks pelajaran fisika yang digunakan di negara bagian Victoria, Australia antara tahun 1967 sampai 1997. Penelitian tersebut memberikan hasil bahwa muatan literasi sains dalam buku berbeda-beda, namun yang mendekati seimbang yaitu $42 \%$ untuk sains sebagai batang tubuh pengetahuan, 19\% sains sebagai cara menyelidiki, 19\% sains sebagai cara berpikir dan $20 \%$ interaksi antara sains, teknologi dan masyarakat atau secara umum memiliki perbandingan $2: 1: 1: 1$.

Pengembangan bahan ajar berbasis literasi sains telah dilakukan pula olehSari, D. L, A. Rusilowati \& S. Linuwih. (2015)serta Safitri, A. D, A. Rusilowati \& Sunarno(2015). Ketiga bahan ajar hasil pengembangan tersebut memiliki perbandingan muatan literasi sains yang mendekati seimbang sebagaimana mengacu pada penelitian Wilkinson. Berdasarkan ketiga penelitian tersebut, maka bahan ajar yang dikembangkan pada penelitian ini dapat dikatakan telah memiliki komposisi muatan literasi sains yang seimbang.

Tingkat kelayakan bahan ajar diuji dengan menggunakan angket kelayakan bahan ajar. Indikator penilaian kelayakan buku mengacu pada kriteria Badan Standar Nasional Pendidikan yaitu aspek kelayakan isi, teknik penyajian, penilaian bahasa, dan kegrafisan (BSNP, 2007) serta satu aspek literasi sains menurut Chiapetta, et.al(1991). Angket diberikan kepada 3 pakar ahli yaitu satu dosen dan dua guru SMA.Hasil uji kelayakan bahan ajar dapat dilihat pada Tabel 2. 
Tabel 2. Hasil Uji Kelayakan Bahan Ajar

\begin{tabular}{|c|c|c|c|c|c|c|}
\hline \multirow[b]{2}{*}{ No } & \multirow[b]{2}{*}{ Kode } & \multicolumn{5}{|c|}{ Validasi (\%) } \\
\hline & & $\begin{array}{c}\text { Kelayakan } \\
\text { Isi }\end{array}$ & $\begin{array}{l}\text { Kelayakan } \\
\text { Penyajian }\end{array}$ & $\begin{array}{c}\text { Penilaian } \\
\text { Bahasa }\end{array}$ & $\begin{array}{c}\text { Kelayakan } \\
\text { Grafis }\end{array}$ & $\begin{array}{c}\text { Literasi } \\
\text { Sains }\end{array}$ \\
\hline 1 & $\mathrm{~V}-1$ & 90,63 & 92,50 & 94,23 & 93,18 & 87,03 \\
\hline 2 & $\mathrm{~V}-2$ & 84,34 & 88,75 & 84,62 & 88,64 & 89,81 \\
\hline 3 & V-3 & 93,75 & 93,75 & 92,30 & 90,90 & 85,18 \\
\hline \multicolumn{2}{|c|}{ Rata-rata } & 89,58 & 91,67 & 90,38 & 90,90 & 87,34 \\
\hline \multirow{2}{*}{\multicolumn{2}{|c|}{ Kriteria }} & Sangat & Sangat & Sangat & Sangat & Sangat \\
\hline & & layak & layak & layak & layak & layak \\
\hline
\end{tabular}

Analisis tingkat keterbacaan bahan ajar berbasis literasi sains dilakukan menggunakan tes rumpang dengan melibatkan 38 siswa kelas eksperimen sebagai responden. Hasil uji keterbacaan menunjukkan bahwa bahan ajar yang digunakan memiliki kriteria mudah dipahami dengan rata-rata keterbacaan sebesar $74,11 \%$.Kriteria mudah dipahami mengindikasikan bahwa siswa mengerti maksud kalimat yang ditulis dalam bahan ajar.

Meskipun hasil keterbacaan bahan ajar memiliki kriteria mudah dipahami, namun ada 5 siswa yang hanya memenuhi syarat keterbacaan. Hasil yang berbeda dari tiap siswa ini dipengaruhi oleh beberapa faktor. Perbedaan hasil yang diperoleh siswa kemungkinan disebabkan karena perbedaan kemampuan memahami dan pengelolaan kegiatan belajar siswa yang berbeda.Fakta tersebut sejalan dengan pendapat Keller (1983) dalam Abdurrahman (2009) yang menjelaskan bahwa hasil belajar merupakan fungsi dari masukan pribadi (personal input) dan masukan yang berasal dari lingkungan (environmental input). Masukan pribadi terdiri dari: (1) motivasi atau nilai-nilai, (2) harapan untuk berhasil (expectancy), (3) intelegensi dan penguasaan awal, serta (4) evaluasi kognitif sedangkan masukan yang berasal dari lingkungan meliputi: (1) pengelolaan motivasional, (2) pengelolaan kegiatan belajar, dan (3) pengelolaan penguatan (reinforcement).

Untuk meningkatkan tingkat keterbacaan perlu dilakukan perbaikan bahan ajar dengan cara menelaah kembali kata atau kalimat dalam bahan ajar. Sakri berpendapat bahwa keterbacaan (readability) bergantung pada kosakata dan bangun kalimat yang dipilih oleh pengarang untuk tulisannya (Kemdikbud, 2012). Penggunaan kosakata yang tidak umum akan lebih sulit dipahami daripada yang menggunakan kosakata yang sudah dikenal. Selain itu, struktur kalimat yang panjang dan kompleks akan menyulitkan pembaca untuk 
memahami bacaan. Oleh karena itu, kata atau kalimat yang dijawab salah oleh sebagian besar siswa kemudian diperbaiki atau diganti dengan kata yang lebih familiar dan kalimat yang lebih efektif. Perbaikan ini bertujuan agar bahan ajar yang dikembangkan lebih mudah untuk dipahami oleh penggunanya.

Bahan ajar berbasis literasi sains yang dikembangkan diuji keefektifannya dengan melaksanakan post-test. Hal ini bertujuan untuk mengetahui apakah peningkatan kemampuan literasi sains siswa kelas eksperimen lebih tinggi daripada kelas kontrol.Pengujian data menggunakan uji gainberdasarkan nilai pretest-posttest siswa kelas kontrol dan kelas eksperimen. Hasil peningkatan kemampuan literasi sains siswa ditunjukkan pada Tabel 3.

Tabel 3. Hasil Peningkatan Kemampuan Literasi Sais Siswa

\begin{tabular}{cccc}
\hline Hasil & Kelompok Eksperimen & Kelompok Kontrol \\
\hline & Uji gain & 0,63 & 0,38 \\
Uji t & & 7,5739 & \\
\hline
\end{tabular}

Berdasarkan analisis uji kesamaan dua rata-rata diperoleh $t_{\text {hitung }}=7,5739$ dan $t_{\text {tabel }}=$ 1,665 dengan $\alpha=5 \%$ dan $\mathrm{dk}=76-2=74$. Data yang diperoleh menunjukkan bahwa nilai $t_{\text {hitung }}$ berada di luar daerah penerimaan Ho sehingga Ho ditolak dan Ha diterima. Dengan demikian dapat diartikan bahwa peningkatan kemampuan literasi sains siswa yang menggunakan bahan ajar yang dikembangkan lebih tinggi daripada siswa yang menggunakan bahan ajar yang dipakai di sekolah.

Hasil kemampuan literasi sains siswa kelas kontrol dan kelas eksperimen ditampilkan pada Gambar 2.

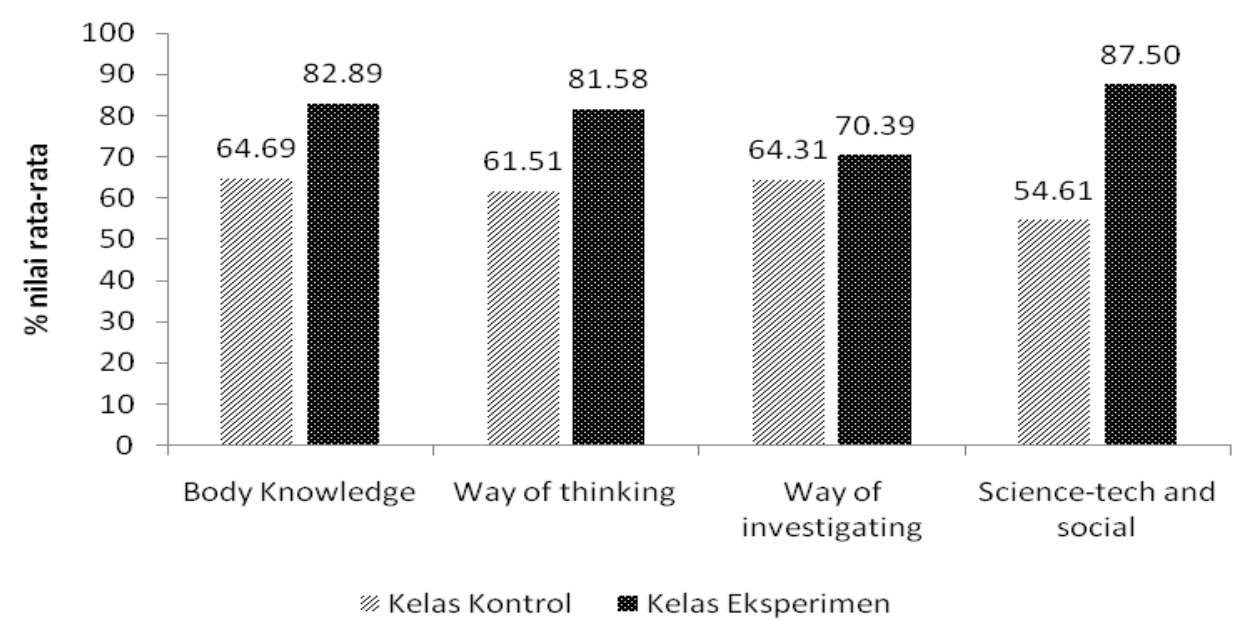

Gambar 2. Kemampuan Tiap Aspek Literasi Sains Kelas Kontrol dan Eksperimen 
Aspek literasi sains tertinggi pada kelas eksperimen adalah interaksi sains, teknologi dan masyarakat, peringkat kedua adalah sains sebagai batang tubuh pengetahuan, peringkat ketiga adalah sains sebagai cara untuk menyelidiki dan yang terendah adalah sains sebagai cara untuk berpikir. Aspek interaksi sains, teknologi dan masyarakat yang menempati posisi pertama dengan persentase $82,89 \%$ menunjukkan bahwa siswa telah memiliki keterampilan menggunakan sains pada berbagai peristiwa dalam kehidupan.Hasil ini sesuai dengan penelitian Agustini (2013) yang menunjukkan bahwa penggunaan model pembelajaran sains, teknologi dan masyarakat dapat meningkatkan keterampilan pemecahan masalah IPA dalam kehidupan sehari-hari. American National Science Teachers Association (NSTA) bahkan menganggap bahwa interaksi antara sains, teknologi dan masyarakat menjadi dasar pendidikan sains karena menekankan pentingnya mengajarkan hubungan interaktif antara ilmu pengetahuan, teknologi dan masyarakat dalam pengambilan keputusan pada masalah sehari-hari (Mansour, 2009).

Berdasarkan analisis hasil post-testkelas kontrol, aspek literasi sains yang paling tinggi adalah sains sebagai batang tubuh pengetahuan. Hasil analisis tersebut mencerminkan bahwa penggunaan buku ajar yang ada selama ini lebih menekankan kepada dimensi konten daripada dimensi proses dan konteks sebagaimana dituntut oleh PISA (Firman, 2007). Hasil ini sejalan dengan penelitian yang dilakukan Maturradiyah, N \& A. Rusilowati (2015) tentang analisis buku ajar fisika SMA di kabupaten Pati berdasarkan muatan literasi sains. Penelitian tersebut menunjukkan bahwa buku ajar yang beredar banyak mengandung pengetahuan, sedangkan aktivitas berpikir, menyelidiki dan interaksi sains, teknologi dan masyarakat sangat sedikit.

Kemampuan siswa pada aspek sains sebagai cara berpikir masih tergolong rendah karena soal-soal latihan yang terdapat pada buku ajar yang digunakan pada kelas kontrol lebih banyak meminta siswa untuk melakukan perhitungan dengan menggunakan rumus secara langsung, atau seolah-olah siswa hanya memasukkan besaran yang diketahui ke dalam rumus yang ada kemudian menghitungnya. Soal-soal yang membutuhkan penggunaan konsep masih kurang sehingga siswa tidak terbiasa menjawab soal post-test dengan tipe soal seperti itu. Oleh karena itu, untuk meningkatkan hasil belajar diperlukan pembiasaan sebagaimana dikemukakan Rusilowati (2011) bahwa untuk mengembangkan kemampuan mahasiswa dalam mengkonstruk konsep tidak dapat dilakukan secara spontan. Agar dapat mengembangkan suatu peta konsep, mahasiswa perlu diberi latihan atau pembiasaan terlebih dahulu. Eggen (2012:110) juga menyatakan bahwa semakin sering siswa belajar tentang satu topik, semakin baik mereka mampu berpikir tentang topik itu. Dengan demikian, semakin 
sering siswa dihadapkan pada soal analisis dan penggunaan konsep maka semakin baik pula kemampuan mereka.

Meskipun demikian, persentase kemampuan literasi sains siswa kelas eksperimen lebih tinggi daripada kelas kontrol, baik pada aspek sains sebagai batang tubuh pengetahuan, sains sebagai cara untuk menyelidiki, sains sebagai cara untuk berpikir, maupun interaksi sains, teknologi dan masyarakat.

\section{KESIMPULAN}

Berdasarkan hasil penelitian, bahan ajar berbasis literasi sains materi suhu dan kalor yang dikembangkan memiliki karakteristik muatan literasi sains yang seimbang, yaitu $37,89 \%$ sains sebagai batang tubuh pengetahuan, 20,10\% sains sebagai cara menyelidiki, $22,75 \%$ sains sebagai cara berpikir, dan 19,26\% interaksi sains, teknologi dan masyarakat.Bahan ajar berbasis literasi sains materi suhu dan kalor dinyatakan layak oleh tiga validator dan memiliki kriteria mudah dipahami dengan rata-rata keterbacaan $74,11 \%$. Peningkatan kemampuan literasi sains siswa yang menggunakan bahan ajar berbasis literasi sains lebih tinggi daripada siswa yang menggunakan bahan ajar yang dipakai di sekolah. Peningkatan kemampuan literasi sains yang menggunakan bahan ajar berbasis literasi sains sebesar 0,63 sedangkan siswa yang menggunakan buku yang dipakai di sekolah sebesar 0,38.

\section{DAFTAR PUSTAKA}

Agustini, D., I.W. Subagia, \& I.N. Suardana.2013.Pengaruh Model Pembelajaran Sains Teknologi Masyarakat (STM) Terhadap Penguasaan Materi dan Keterampilan Pemecahan Masalah Siswa Pada Mata Pelajaran IPA di MTs Negeri Patas. Jurnal Program Pascasarjana Universitas Pendidikan Ganesha, Vol.3.

BSNP. 2007. Kegiatan Penilaian Buku Teks Pelajaran Pendidikan Dasar dan Menengah. Buletin BSNP, 2 (1): 14-23.

Chiappetta, E.L., D.A Fillman, \& G.H. Sethna. 1991. A Method to Quantify Major Themes of Scientific Literacy in Science Textbooks. JournalOf Research In Science Teaching, 28(8): 713-725.

Eggen, P \& D. Kauchak. 2012. Strategi dan Model Pembelajaran: Mengajarkan Konten dan Keterampilan Berpikir. Diterjemahkan oleh Satrio Wahono. 2012. Jakarta: Indeks.

Kemdikbud. 2012. Analisis Hasil Belajar Peserta Didik Dalam Literasi Membaca Melalui Studi Internasional PIRLS 2011. Tersedia di http://litbang.kemdikbud.go.id[diakses 01-09-2016].

Mansour, N. 2009. Science-Technology-Society (STS): A new paradigm in Science Education. Bulletin of science, technology and society. 29(4): 287-297.

Marti, N. W. 2010. Pengembangan Media Pembelajaran Pesawat Sederhana untuk Siswa Sekolah Dasar Berbasis Multimedia. Seminar Internasional ISSN 1907-2066. Buleleng: Universitas Pendidikan Ganesha. 
Maturradiyah, N. \& A. Rusilowati. 2015. Analisis Buku Ajar Fisika SMA Kelas XII di Kabupaten Pati Berdasarkan Muatan Literasi Sains. Unnes Physics Education Journal, 4(1):16-20.

OECD-PISA. 2012. PISA 2012 Results in Focus. Paris: OECD-PISA. Tersedia di http://www.oecd.org/pisa/keyfindings/pisa-2012-results-overview.pdf [diakses 24-082015].

Rusilowati, A \& A. Sopyan. 2011. Pengembangan Concept-Mapping Assesment untuk Mengukur Kemampuan Mahasiswa Mengkonstruk Konsep Elektronika. Jurnal Pendidikan Fisika Indonesia 7: 13-16.

Rusilowati, A. 2013. Peningkatan Literasi Sains Siswa Melalui Pengembangan Instrumen Penilaian:Pidato Pengukuhan Profesor. Semarang: Universitas Negeri Semarang.

Rusilowati, A., Supriyadi \& A. Widiyatmoko. 2015. Pembelajaran Kebencanaan Alam Bervisi SETS Terintegrasi dalam Mata Pelajaran Fisika Berbasis Kearifan Lokal. Jurnal Pendidikan Fisika Indonesia 11 (1): 42-48.

Safitri, A. D, A. Rusilowati \& Sunarno. 2015. Pengembangan Bahan Ajar IPA Terpadu Berbasis Literasi Sains Bertema Gejala Alam. Unnes Physics Education Journal 4 (2): $32-40$.

Sari, D. L, A. Rusilowati \& S. Linuwih. 2015.Pengembangan Bahan Ajar IPA Terpadu Berbasis Literasi Sains Bertema Gejala Alam. Unnes Physics Education Journal 4 (3): 36-42.

Sugiyono. 2009. Metode Penelitian Kuantitatif, Kualitatif dan R\&D. Bandung: Alfabeta.

Wilkinson, J. 1999. A Quantitative Analysis of Physics for Scientific Literacy Themes. Research in Science Education, 29 (3): 385-399. 